\title{
Evaluation of Selected Properties of Steel 100Cr6 at Different Ways of Heat Treatment
}

Peter Fabian, Andrej Zrak

Faculty of Mechanical Engineering, University of Žilina, Univerzitná 1, 01008 Žilina. Slovak Republic. E-mail: peter.fabian@fstroj.uniza.sk, andrejzrak@gmail.com

This study discusses the impact of heat treatment conditions on the final properties of quenched and low-tempered bearing components in terms of microstructure, hardness and impact strength. Technological process of heat treatment must be done rationally and in addition to the required hardness must also ensure the dimensional precision of bearings components. Different austenitization conditions have a great influence on the phenomena which takes place in the material during the austenitizing. Heat treatment of rolling bearing components is an indispensable part of their production and it is also an unavoidable item of the price calculation of bearings. The aim of a competitive struggle for the rolling bearings market is an offer of the best quality bearings (dimensional accuracy, stability and durability) at a reasonable price.

Keywords: austenitizing, bearing steel, quenching, heat treatment

\section{Acknowledgement}

This contribution was made with the financal assistance of KEGA agency, project No. 042ŽU-4/2015 and APVV SKPL-2015-0008

\section{References}

[1] DURAND-CHARE, M. (2004). Microstructure of Steels and Cast Irons, Springer, Berlin.

[2] LIŠČIĆ, B et al. (2010). Quenching Theory and Technology 2nd edition, Taylor \& Francis Group LLC, Boca Raton.

[3] PUTGEN, W. (2007). On the microstructure and properties of 100Cr6 steel processed in the semi-solid state, Acta Materialia 55 (19): 6553-6560, Elsevier, Amsterdam.

[4] KOŇÁR, R., MIČIAN, M., HLAVATÝ, I. (2014). Defect detection in pipelines during operation using Magnetic Flux Leakage and Phased Array ultrasonic method. In: Manufacturing technology, Vol. 14, No. 3, pp. 337-341. J. E. Purkyne University, Ústi nad Labem.

[5] KOŇÁR, R., MIČIAN, M. (2014). Non-destructive testing of welds in gas pipelines repairs with Phased Array ultrasonic technique. In: Manufacturing technology, Vol. 14, No. 1, pp. 42-47. J. E. Purkyne University, Ústi nad Labem.

[6] DOPJERA, D., KOŇÁR, R., MIČIAN, M. (2014) Ultrasonic testing of girth welded joint with TOFD and Phased Array. In: Manufacturing technology, Vol. 14, No. 3, pp. 281-286.

[7] DOPJERA, D., MIČIAN, M. (2014) The detection of articullary made defects in welded joint with ultrasonic defectoscopy Phased Array. In: Manufacturing Technology, Vol. 14, No. 1, pp. 12-17, ISSN 1213-2489

[8] PASTIRČÁK, R. (2014) Effect of low pressure application during solidification on microstructure of AlSi alloys In: Manufacturing Technology, Vol. 14, No. 3, pp. 397- 402, ISSN 1213-2489

[9] PATEK, M., KOŇÁR, R., SLÁDEK, A., RADEK, N. (2014) Non-destructive testing of split sleeve welds by the ultrasonic TOFD method In: Manufacturing technology. ISSN 1213-2489. - Vol. 14, No. 3 (2014), s. 403-407.

[10] KOŇÁR, R., MIČIAN, M., MEŠKO, J., SVENTEK, M. (2015). Identification of lack of fusion and penetration in circumferential fillet weld by phased array ultrasonic method in gas industry In: Communications : scientific letters of the University of Žilina. - ISSN 1335-4205. - Vol. 17, No. 3 (2015), s. 98-102.

[11] NOVÁK, P., MEŠKO, J., ŽMINDÁK, M. (2013) Finite element implementation of multi-pass fillet weld with phase changes In: Manufacturing technology. - ISSN 1213-2489. - Vol. 13, No. 1 (2013), s. 79-85.

[12] PODPROCKÁ, R., BOLIBRUCHOVÁ, D., MALIK, J. (2015) Defects in high pessure die casting process [Defekty pri procese vysokotlakového liatia] / Radka Podprocká, Jozef Malik, Dana Bolibruchová. In: Manufacturing technology: journal for science, research and production. - ISSN 1213-2489. - Vol. 15, No. 4, s. 674-678.

[13] ŽIHALOVÁ, M., BOLIBRUCHOVÁ, D., CAIS, J. (2015). Microstructural analysis of nickel influence in Alsi10MgMn alloy with increased iron level [Mikroštruktúrna analýza vplyvu niklu v zliatine so zvýšenou úrovňou železa AlSi10Mg. In: Manufacturing technology. ISSN 1213-2489. - Vol. 15, No. 4, s. 743-748.

[14] RICHTÁRECH, L. BOLIBRUCHOVÁ, D. (2014) Effect of selected elements on the microstructure of secondary Al-Si alloys In: Manufacturing technology. ISSN 1213-2489. - Vol. 14, No. 3, s. 431-437. 